\title{
Nutritional and morphostructural characterization of pre-dried winter grass silage
}

\section{Caracterização morfoestrutural e valor nutritivo de silagem pré- secada de culturas de inverno}

\author{
Márcio Simionatto ${ }^{1}$; Emilyn Midori Maeda ${ }^{2}$; Ana Carolina Fluck ${ }^{2 *}$; Allan Patrick \\ Silveira'; Francisco Antônio Piran Filho ${ }^{1}$; Fabiana Luiza Matielo de Paula ${ }^{3}$; Olmar \\ Antônio Denardin Costa ${ }^{3}$; Lilian Regina Rothe Mayer ${ }^{2}$; Vicente de Paulo Macedo ${ }^{2}$
}

\begin{abstract}
The aim was to evaluate the productive quality and fermentative as like the nutritional parameters of winter grass silage in the vegetative and reproductive stages in two consecutive crop years. The experiment was carried out at Universidade Tecnológica Federal do Paraná, Campus Dois Vizinhos, Brazil, from April 2012 to December 2013. The experimental field had a $560 \mathrm{~m}^{2}$ area; it comprised 32 plots of $16 \mathrm{~m}^{2}$ each, with a space of $0.5 \mathrm{~m}$ between blocks. Four winter grass species were used, including Avena sativa L. 'IPR 126' (white oat), Avena strigosa Schreb. 'IAPAR 61' (lopsided oat), Lolium multiflorum Lam. 'Barjumbo' (ryegrass), and Secale cereale L. 'Temprano' (rye), being evaluated through silage making in two phenological stages, vegetative and reproductive. The experimental design was randomized block in a bifactorial scheme (cultivar and phenological phase of pasture). The experimental materials were ensiled in polyvinyl chloride (PVC) microsiles, with four replicates per treatment. Pre-drying and ensiling allowed the preservation of material quality. The highest yields of dry matter per hectare were obtained in the reproductive stage; however, the nutritive content at this stage was relatively lower when compared with vegetative. The rye presented relatively less variation of the nutritional composition between the studied phenological stages. The ash content of the forage influenced the $\mathrm{pH}$ of the silage, and the highest $\mathrm{pH}$ was verified at the vegetative stage. Even with pre-dehydration, the vegetative stage presented a greater loss of effluents than the reproductive stage.
\end{abstract}

Key words: Avena sativa. Avena strigosa. Lolium multiflorum. Secale cereale. silage. Phenological stage.

\section{Resumo}

O objetivo foi avaliar a qualidade produtiva, parâmetros fermentativos e nutricionais da silagem das gramíneas temperadas nos estágios vegetativo e reprodutivo em dois anos consecutivos de cultivo. O trabalho foi conduzido na Universidade Tecnológica Federal do Paraná, Campus Dois Vizinhos - PR de abril de 2012 a dezembro de 2013. A área experimental possuía $560 \mathrm{~m}^{2}$, divididos em 32 parcelas de $16 \mathrm{~m}^{2}$ cada, com 0,5 m de espaçamento entre blocos. As gramíneas avaliadas foram: Aveia Branca cv.

1 Discentes. Programa de Pós-Graduação em Zootecnia, Universidade Tecnológica Federal do Paraná, UTFPR, Dois Vizinhos, PR, Brasil.E-mail: marciosmto@hotmail.com; allanpatrick_silveira@hotmail.com; chicofapf@gmail.com

2 Profs., Coordenação do Curso de Zootecnia, UTFPR, Dois Vizinhos, PR, Brasil.E-mail: emilyn@utfpr.edu.br; anacarolinafluck@ yahoo.com.br; lilianmayer@utfpr.edu.br; vicentepmacedo@utfpr.edu.br

3 Pós-Doutorandos, Programa de Pós-Graduação em Zootecnia, Universidade Tecnológica Federal do Paraná, UTFPR, Dois Vizinhos, PR, Brasil. E-mail: fabianadepaula3@hotmail.com; odenardin@gmail.com;

Author for correspondence 
IPR 126 (Avena sativa L.), Aveia Preta cv. IAPAR 61 (Avena strigosa Schreb.), Azevém cv. Barjumbo (Lolium multiflorum Lam.) e Centeio cv. Temprano (Secale cereale L.), através da confecção de silagem pré-secada em dois estádios: vegetativo e reprodutivo. O delineamento experimental utilizado foi blocos ao acaso em esquema fatorial, avaliando o fator cultivar e o fator estádio fenológico das gramíneas. Foram avaliadas a qualidade nutricional e parâmetros fermentativos da silagem, assim como seu respectivo estádio fenológico. As forrageiras foram ensiladas em microssilos experimentais de PVC, com 4 repetições por tratamento. A pré-secagem e a ensilagem possibilitaram a conservação e qualidade do material. As maiores produções de matéria seca por hectare foram obtidas na fase reprodutiva, no entanto, a composição nutricional nesta fase apresentou teores inferiores comparados ao da fase vegetativa. O centeio apresentou menor variação da composição nutricional entre os estádios fenológicos estudados. O conteúdo mineral da forrageira influencia no $\mathrm{pH}$ da silagem, sendo que $\mathrm{pH}$ mais elevado é verificado no estádio vegetativo. Mesmo com a pré-secagem, o estádio vegetativo apresenta maior perda por efluentes quando comparada ao estádio reprodutivo.

Palavras-chave: Avena sativa. Avena strigosa. Lolium multiflorum. Secale cereale. Ensilagem. Ciclo reprodutivo.

\section{Introduction}

Seasonality in pasture animal production systems has encouraged technicians and researchers to use different forage management techniques. Silage production is a tactic widely used as a supplement during forage deficit periods. Initially described as a possibility of forage conservation for use in times of scarcity, it is now a part of the food base of more modern herds, being used continuously (FLUCK et al., 2018a).

Maize and sorghum are the main crops used for silage production in Brazil. However, the use of other fodder materials with a superior nutritive content has been explored. The use of cold-season grasses, such as ryegrass, oats, and rye, for silage production is a viable alternative during forage shortage periods (FEROLLA et al., 2007). These grass varieties show high animal acceptability, palatability, rich protein contents, and high versatility, and can be supplied in their in natura form or as silage and hay.

In times of high demand of livestock, much attention has been focused on the production of predried silage (ZAMARCHI et al., 2014). Owing to the high nutritional quality and ease of production of pre-dried silage, a wide range of materials are ensiled. However, the main justification for the wide diffusion and viability of this technique in comparison to the haymaking process is the shorter exposure time of the material to the field, avoiding losses caused by rainfall and low temperatures, which occur more frequently in the winter period and depreciation of material quality as well as the cost of machinery (PEREIRA; REIS, 2001).

The factors that determine the quality of silage are the nutritional value and green matter production of forage (FONTANELI et al., 2012), having a direct influence on the compaction and sizing of the silo. In pastures with high moisture content, low fermentation at high $\mathrm{pH}$ can affect the quality of the silage, causing losses, low palatability, and digestibility of the silage material. Ensiling these winter crops without prior drying causes increased nutrient outflow and loss of digestible nutrients.

Another feature that directly affects the quality of silage is the development cycle of the concerned plant species. The advancement of the phenological stage can negatively influence the leaf:stem ratio of plants, with a consequent decrease in their nutritional quality. Usually, when progressing through a phenological stage, plants present a drop in the content of potentially digestible nutrients (PEREIRA; REIS, 2001). In view of the above information, the aim was to evaluate the productive quality, fermentative $\mathrm{pH}$, and effluent losses, as well as nutritional parameters of the silage of temperate grasses, including white oats, lopsided oats, ryegrass, and rye, in their vegetative and reproductive stages in two consecutive crop years. 


\section{Material and Methods}

The work was conducted between April 2012 and December 2013 in an experimental area of the Research Unit of Annual Cultures of the Universidade Tecnológica Federal do Paraná (UTFPR), Câmpus Dois Vizinhos, a municipality located in the southwest region of the State of Paraná in the Third Planalto Paranaense region. The climate of this region was classified as subtropical humid mesotherm (Cfa), according to the classification of Köppen, and the soil was classified as dystrophic Red Latosol (BHERING et al., 2008). During the experimental period, the monthly rainfall varied from 89.8 to $535.6 \mathrm{~mm}$, the minimum temperature was $-1.8^{\circ} \mathrm{C}$, and the maximum temperature was 33 ${ }^{\circ} \mathrm{C}$, averaging between 15.6 and $19.8^{\circ} \mathrm{C}$. This data was collected in an automatic station of INMET, located at Câmpus, with a timetable published by the Group of Studies in Biometeorology (GEBIOMET, 2016) during the period of planting and cultivation of the evaluated fodder.

Two years of cultivation were evaluated. In both years, the following grass species were evaluated in the experiment: Avena sativa L. 'IPR 126' (white oats), Avena strigosa Schreb. 'IAPAR 61' (lopsided oats), Lolium multiflorum Lam. 'Barjumbo' and Secale cereale L.'Temprano' (rye). The experimental design was a randomized block design, with four replications, arranged in a bifactorial scheme, evaluating the qualitative and quantitative differences between the cultivars and phenological stages of the studied grass species. In the vegetative stage, the cuts were performed when the plants were in full tillering stage, with emergence of new tillers, presenting high ratio of leaves. In the reproductive stage, the cuts were performed at the beginning of flowering.

The experimental area was $560 \mathrm{~m}^{2}$, divided into 32 plots of $16 \mathrm{~m}^{2}$ each, with a spacing of 0.5 $\mathrm{m}$ between plots. Soil preparation was carried out in a conventional way under the presence of black mucuna (Mucuna aterrina) from previous years. In the first year, correction fertilization was carried out, using $288 \mathrm{~kg} \mathrm{ha}^{-1}$ of triple superphosphate, $80 \mathrm{~kg} \mathrm{ha}^{-1}$ of potassium chloride, and $144 \mathrm{~kg}$ of $\mathrm{N}$, according to the soil analysis and recommendation for coldseason species (CQFS, 2004). In the second year, NPK base fertilization and N applications were performed according to the dosage recommendations from the production expectation of winter forage crops (CQFS, 2004). Seeds were harvested at the viable pure seed densities of $100,50,25$, and $60 \mathrm{~kg}$ $\mathrm{ha}^{-1}$ for white oat, lopsided oat, ryegrass, and rye, respectively, with $30 \%$ seeds added to compensate for the losses due to implantation methods.

The standardization cut was performed when the plants reached an average height of $25 \mathrm{~cm}$. Subsequently, when they reached a light interception of approximately $95 \%$, the cutting and ensiling of the vegetative-stage plots was carried out. In the reproductive phase, the ensiling was carried out when the grasses started flowering. The cuts were performed on different dates, according to the plant's reproductive development. The residue height was determined in relation to the structure of the plants, being $10 \mathrm{~cm}$ of the soil for lopsided and white oats and $7 \mathrm{~cm}$ for ryegrass and rye.

Luminous interception (LI) and leaf area index (LAI) were evaluated using the SunScan apparatus (SunScan Canopy Analysis System - Delta-T Devices Ltda, Cambridge, United Kingdom). For the readings of LI and LAI, direct sunlight was sampled on the surface of the forage sward and close to the soil. Four distinct points were evaluated within 16 $\mathrm{m}^{2}$ of each plot in order to reduce sampling errors. The schedules were prioritized around midday in order to better capture the solar incidence. These procedures were performed for each plot, regardless of, taking care of each start of the work in a plot, to intercept the direct insolation. LI was estimated as the percentage of light disappearance in the canopy (relationship between the light captured on top of the canopy and sward). Before each cut, two samples were collected in the plots, using a 0.25 $\mathrm{m}^{2}$ square, with samples for structural separation 
(leaves and stems) and forage mass. Afterwards, these samples were sent to a forced circulation air oven at $55^{\circ} \mathrm{C}$ for $72 \mathrm{~h}$. Thus, the forage mass was estimated $\left(\mathrm{kg} \mathrm{ha}^{-1}\right)$, together with the proportion of leaves and stems.

After harvesting, the biomass was left in the field, with stirring every hour, remaining from six to eight hours in this place, until approximately $35 \%$ of dry matter, with monitoring of the moisture of the material according to Souza et al. (2002). Thereafter, the material was chopped with $5 \mathrm{~cm}$ particle stationary chopper and compacted in $500 \mathrm{~cm}^{3}$ experimental PVC microsiles with an approximate density of $650 \mathrm{~kg} \mathrm{~m}^{-3}$ (ANDRIGUETTO et al., 2002). To quantify losses by effluents, $200 \mathrm{~g}$ of oven-dried sand (at $105^{\circ} \mathrm{C}$ for $4 \mathrm{~h}$ ) was packed in TNT bags, which were added to the bottom of the silo, avoiding direct contact of the silage and sand.

Immediately after the silos were opened, the silage samples were taken for determining their $\mathrm{pH}$ values, according to the method described by Detmann et al. (2012), where $9 \mathrm{~g}$ of samples were weighed and submerged for $30 \mathrm{~min}$ in $60 \mathrm{ml}$ of distilled water. Three consecutive $\mathrm{pH}$ readings were taken with the help of a digital potentiometer. Effluent losses were estimated by the equations described by Zanine and Macedo Junior (2006). Chemical analyzes were performed on the silage samples of microsiles and ryegrass, cut in an area of $0.25 \mathrm{~m}^{2}$ in the field. For the determination of pre-dried matter (PDM), the samples were heated in a forced-circulation oven at $55{ }^{\circ} \mathrm{C}$ for $72 \mathrm{~h}$. Subsequently, the samples were milled in Wiley-type mills using a 1-mm sieve screen for chemical analysis. Thus, were analyzed dry matter (DM) by drying at $105{ }^{\circ} \mathrm{C}$ for $24 \mathrm{~h}$, Method 967.03 (AOAC, 1998), ash by performing combustion at $600^{\circ} \mathrm{C}$ for $4 \mathrm{~h}$, and organic matter (OM) by using equation 100-ash, Method 942.05 (AOAC, 1998). The crude protein (CP) levels were determined by the Kjeldahl method, Method 984.13 (AOAC, 1997). The neutral detergent fiber (NDF) and acid detergent fiber (ADF) contents were estimated using the Ankom Fyber Analyzer
A2000®; alpha-amylase (MERTENS, 2002) was included in the analysis of NDF.

Data were submitted to the analysis of variance through a general linear model (GLM) procedure (SAS, 2013), using the following model:

$$
Y i j k l=\mu+\alpha i+b j+e k+a l+\alpha e i k+\varepsilon i j k 1
$$

where $\mu=$ mean of observations; $\alpha i=$ Effect of $\mathrm{i}$-th treatment; $b j=$ effect of the j-th block; ek $=$ Effect of k-th stage; al = effect of the 1st-nth year; $\alpha$ eij $=$ effect of interaction between treatment factors; cijkl $=$ Error.

With a significant difference $(\mathrm{P}=0.05)$, the means of the treatment and phenological stage were compared by the Tukey test. In case of the interaction of treatment factors, the means were compared by a T-test, with the same level of significance, in addition to Pearson's correlation test among the evaluated components.

\section{Results and Discussion}

The rye and ryegrass presented higher LAI values than the other grass species studied (Table 1), and it could be observed that the LI values showed numerical oscillation according to the LAI variation. A value of LAI indicates growth rate, besides favoring the dehydration of the harvested material for hay or pre-drying. However, it reduces the soil moisture losses due to evaporation by presenting a greater soil cover. Brougham (1956), working on different defoliation intensities in ryegrass, reported that the LI values lower than $95 \%$ and the LAI values ranging from 3.5 to 5.0 are critical in the development of temperate climate grasses. However, it can be affirmed that a pasture undergoes changes in its structure as the development cycle progresses, exhibiting a greater proportion of leaves, related to higher LAI values, in the vegetative stage and a marked decrease of this structure upon reaching the reproductive stage (AGUINAGA et al., 2008). 
Table 1. Structural characteristics of winter grasses in two phenological stages. Dois Vizinhos, PR, $2012 ; 2013$.

\begin{tabular}{|c|c|c|c|c|c|c|}
\hline Grass & Phenological stage ${ }^{2}$ & LAI & $\mathrm{LI}^{1}$ & Leaves $^{1 \S}$ & Stems $^{1 \S}$ & Forage mass $^{1}$ \\
\hline \multirow{2}{*}{ Lopsided oat } & $\mathrm{V}$ & $7.18 \pm 0.66$ & 97.4 & 56.0 & 42.8 & 2834.67 \\
\hline & $\mathrm{R}$ & $6.32 \pm 0.76$ & 98.4 & 38.61 & 38.74 & 7010.33 \\
\hline \multirow{2}{*}{ White oat } & $\mathrm{V}$ & $6.18 \pm 1.10$ & 97.0 & 68.01 & 29.89 & 2765.06 \\
\hline & $\mathrm{R}$ & $6.83 \pm 1.12$ & 97.1 & 37.06 & 42.22 & 5640.29 \\
\hline \multirow{2}{*}{ Rye } & $\mathrm{V}$ & $7.8 \pm 0.68$ & 98.7 & 66.12 & 33.88 & 1999.6 \\
\hline & $\mathrm{R}$ & $7.56 \pm 0.81$ & 98.7 & 52.19 & 35.67 & 4050.13 \\
\hline \multirow{2}{*}{ Ryegrass } & V & $7.33 \pm 1.25$ & 98.7 & 69.14 & 27.13 & 1654.77 \\
\hline & $\mathrm{R}$ & $7.96 \pm 0.91$ & 98.4 & 48.8 & 33.11 & 4070.4 \\
\hline Standard error & & 0.91 & - & - & - & - \\
\hline $\mathrm{P} \leq 0.05$ & & *; ns;ns & - & - & - & - \\
\hline
\end{tabular}

LAI: Leaf Area Index; LI:\% Luminous Interceptation; Forage Mass: kg MS ha ${ }^{-1}{ }^{1}{ }^{1}$ Descriptive data; $\S:$ Contribuition on forage mass in percent; \pm Standard Deviation; Two-year growing averages; ${ }^{2}$ Phenological Stage: V: Vegetative; R: Reprodutive; $\mathrm{P} \leq 0.05: \mathrm{F}$ test with $\alpha=0.05$, for the factors grass, stage, and interaction between grass*stage; *:Significative; ns: Not Significative.

The pre-drying aided in increasing the DM contents to the values close to those desired (Table 2); however, a staining effect was observed in the contents of this variable. Vanbelle et al. (1983) commented that the pre-drying technique is used to cut the forage, following the pre-wilting treatment, until the material reaches 30 to $45 \%$ dry mass. In order for the fermentation process of the silage to take place within the indicated time, it is necessary to take into account the DM content of a forage species before selecting it for use. This determines whether the techniques that aim to minimize nutrient leaching losses, such as pre-drying and use of additives, are required. In this study, all treatments presented satisfactory DM contents, contributing to rapid oxygen uptake after micro-silage sealing, a determinant factor for the initiation of silage fermentation (McDONALD, 1981).

Table 2. Chemical composition of pre-ensiled of winter grasses in two different phenological stages. Dois Vizinhos, PR, 2012 e 2013.

\begin{tabular}{lccccccc}
\hline \multirow{2}{*}{ Grass } & $\begin{array}{c}\text { Phenological } \\
\text { stage }^{2}\end{array}$ & \multicolumn{7}{c}{ Chemical composition } \\
\cline { 3 - 8 } Lopsided oat & $\mathrm{V}$ & $352.2 \pm 4.58$ & $893.9 \pm 10.4$ & $106.1 \pm 10.4$ & $261.4 \pm 34.8$ & $524.6 \pm 25.3$ & $250.0 \pm 22.6$ \\
& $\mathrm{R}$ & $375.8 \pm 2.72$ & $927.3 \pm 10.9$ & $72.7 \pm 10.9$ & $195.0 \pm 24.5$ & $622.4 \pm 32.7$ & $337.1 \pm 45.2$ \\
\multirow{2}{*}{ White oat } & $\mathrm{V}$ & $348.1 \pm 3.7$ & $900.0 \pm 17.7$ & $100.0 \pm 17.7$ & $233.7 \pm 16.3$ & $539.1 \pm 57.4$ & $266.5 \pm 42.0$ \\
& $\mathrm{R}$ & $371.2 \pm 2.79$ & $930.4 \pm 8.30$ & $69.6 \pm 8.30$ & $187.9 \pm 30.5$ & $610.2 \pm 24.1$ & $324.8 \pm 18.7$ \\
\multirow{2}{*}{ Rye } & $\mathrm{V}$ & $351.9 \pm 7.8$ & $892.0 \pm 18.7$ & $108.0 \pm 18.7$ & $265.1 \pm 12.5$ & $523.5 \pm 35.1$ & $244.5 \pm 10.4$ \\
& $\mathrm{R}$ & $374.0 \pm 2.5$ & $924.7 \pm 4.03$ & $78.1 \pm 4.03$ & $223.8 \pm 20.8$ & $583.3 \pm 61.5$ & $278.7 \pm 19.6$ \\
\multirow{2}{*}{ Ryegrass } & $\mathrm{V}$ & $349.6 \pm 8.7$ & $884.7 \pm 19.2$ & $115.3 \pm 19.2$ & $252.8 \pm 38.1$ & $522.3 \pm 23.8$ & $218.5 \pm 13.5$ \\
& $\mathrm{R}$ & $373.7 \pm 3.9$ & $919.7 \pm 18.9$ & $80.3 \pm 18.9$ & $205.9 \pm 19.6$ & $559.5 \pm 28.9$ & $258.9 \pm 32.6$ \\
\hline Standard Error & & 5.14 & 18.14 & 13.34 & 16.56 & 39.02 & 28.25 \\
P $\leq 0.05$ & & $\mathrm{~ns} ; * ; \mathrm{ns}$ & $\mathrm{ns} ; * ; \mathrm{ns}$ & $\mathrm{ns} ; * ; \mathrm{ns}$ & $* ; * ; \mathrm{ns}$ & $* ; * ; \mathrm{ns}$ & $* ; * * *$ \\
\hline
\end{tabular}

$\S$ Values express in $\mathrm{g} \mathrm{kg}^{-1}$ of Dry Matter; $\S \S$ : Values express in $\mathrm{g} \mathrm{kg}^{-1}$ of Natural Matter; DM: Dry Matter; OM: Organic matter; CP: Crude Protein; NDF: Neutral Detergent Fiber; ADF: Acid Detergent Fiber; \pm Standard Deviation; Two-year growing averages; ${ }^{2}$ Phenological Stage: V: Vegetative; R: Reprodutive; $\mathrm{P} \leq 0.05$ : F test with $\alpha=0.05$, for the factors grass, stage, and interaction between grass*stage; *:Significative; ns: Not Significative. 
The ash and OM contents were influenced only by the stage of development, the upper ash being in the vegetative stage and the $\mathrm{OM}$ in the reproductive stage, indicating a direct relationship between the ash and OM contents and thickness of a plant cell wall, since, young plants present cells with higher soluble content and less thick walls (FLUCK et al., 2018b). With the advancement of the development cycle, a plant gradually changes the type of accumulated tissues, exhibiting an increase in support tissues (VAN SOEST, 1994), such as stems, in this case, reflecting an increase in fibrous fractions.

The CP content presented a significant difference, both among cultivars and phenological stages. It was noticed that in all cuttings, the rye stood out in relation to the $\mathrm{CP}$ content. This was attributed mainly to its high nutritional value derived from tender leaves and rapid reestablishment of the crop after cutting, with a relatively long development cycle (FONTANELI et al., 2009). Furthermore, the decrease in $\mathrm{CP}$ content with the evolution of a phenological stage was low, varying by approximately 6 percentage points for the cultivars studied. Rodrigues et al. (2002), working with different forage species in the lowlands, recorded the average $\mathrm{CP}$ values ranging from $16 \%$ to $19.0 \%$. In addition, they found differences in the $\mathrm{CP}$ content in relation to the phenological stage, as indicated by a decrease of approximately 3 percentage points during progression to the reproductive stage.

A gradual increase in the contents of NDF and ADF was observed with the interaction between treatment factors. With the advancement of the phenological stage, the NDF level was higher for all grass species. This result can be justified because, at this stage, grasses generally have a lower leaf/ stem ratio, increased fibrous content, and decreased soluble content (VAN SOEST, 1994; COSTA et al., 2018). In addition, plant and botanical changes, such as the elongation of internodes and emergence of inflorescences, occur in a pasture, resulting in a decrease in its nutritive value of pastures (SKONIESKI et al., 2011; COSTA et al., 2018).
In the silage, the DM contents presented variation only in the phenological stage factor. The contents of OM and ash presented the same behavior as in the pre-silage material. These variables are extremely important in silage because they are directly related to the silage quality and the material's buffering power. The mineral content might increase the ability of the material to withstand $\mathrm{pH}$ variation (PLAYNE; McDONALD, 1966)

The CP losses in the silage and pre-ensiled material were not evaluated. It is worth noting that regardless of the silage process efficiency, the maximum obtainable output of the silage process is the maintenance of the nutritional value of the silage material, and if it is done in an erroneous way, the quality can easily be impaired (JOBIM et al., 2007). The protein levels decreased with the progress of the development stage in all grass species, being observed significant difference in the protein levels between the grass species. Meinerz et al. (2011), evaluating the silage of different winter cereals, also found a difference in the protein levels between the cultivars evaluated. Boin et al. (2005), when searching for silages from white oats, found that the protein levels varied according to the stage of development, with the $\mathrm{CP}$ content decreasing at the reproductive stage. However, Fluck et al. (2018b) reported a decrease of approximately $64 \%$ in the $\mathrm{CP}$ content of the silage when the plants progressed from the vegetative to the flowering stage.

The NDF content of the silage was numerically lower than that of the fresh silage material (Table 2 and 3). This difference occurs through the pruning and fermentation processes, breaking the cell wall, leaving the material with the greater surface exposed, and thus, contributing to the action of microorganisms in the fiber. This behavior is contrary to the expected, since the losses of nonstructural compounds in the fermentation process usually increase the fiber fraction content in the forage. However, the disappearance of this percentage of NDF indicates that the hemicellulose fraction might have been solubilized. 


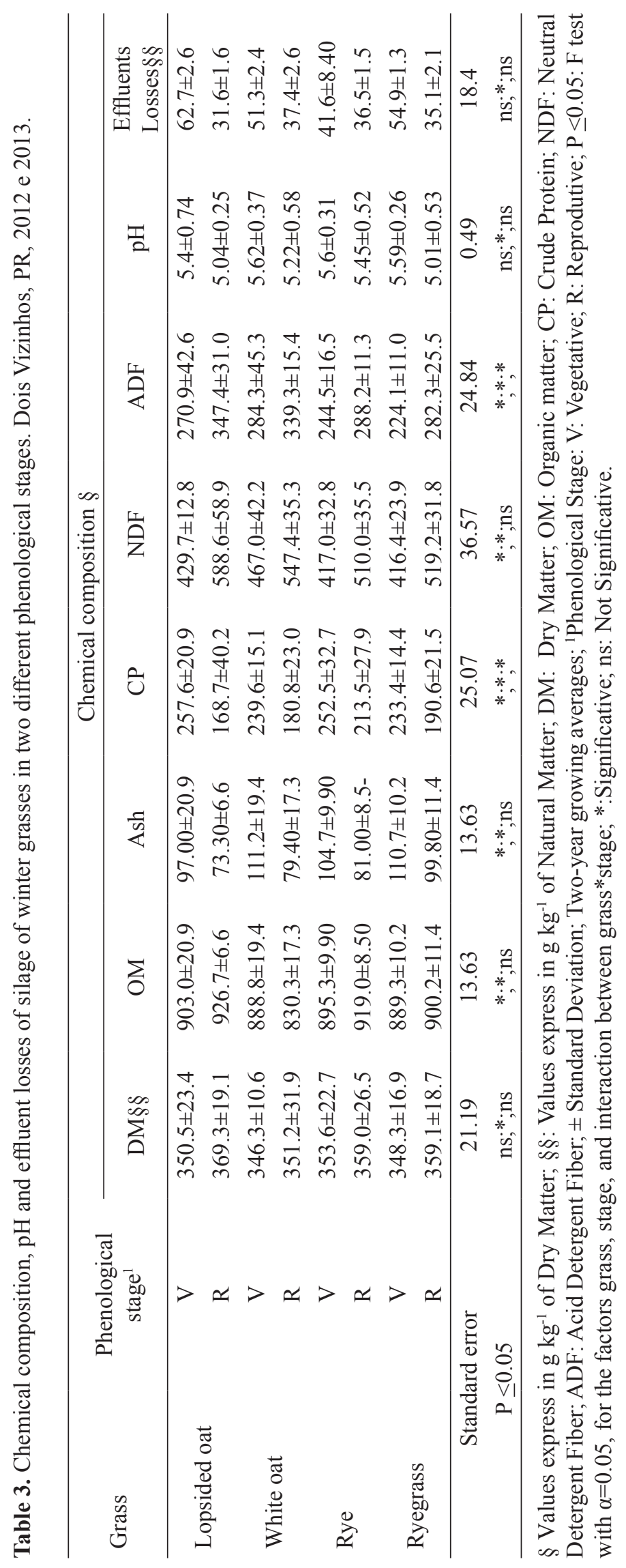


In both stages, the lowest levels of NDF were found in ryegrass and rye. Among the two stages, the NDF content increased according to the progression of the stages, being the highest in the reproductive stage, when the quality of the forage diminishes drastically (PARIS et al., 2015). An increase in the NDF content was found to be the primary factor for the decline in the nutritional quality of a forage species (KOZLOSKI et al., 2005). In addition, it was found that the NDF content presented a negative correlation with the mineral matter and protein contents $(\mathrm{CP}:-0.71, \mathrm{P}=0.0001$; Ash: $-0.54, \mathrm{P}=$ $0.0001)$.

For the ADF content, significant differences were observed with the interaction between the two factors studied. As for the NDF content, the lowest values were observed for ryegrass silage and rye silage in both stages, being superior at the reproductive stage compared to the vegetative stage. In agreement with our findings, Lopes et al. (2008), evaluating oat silages at different cutting ages, observed an increase in the levels of ADF with an increase in the cutting age.

Mesquita and Neres (2008) reported that as a consequence of the fast development of grasses, their cellular nutrient content decreased with increasing age, leading to an accumulation of lowdigestibility nutrients because of the increase in the content of cell wall compounds, such as NDF and $\mathrm{ADF}$, to the detriment of CP. However, despite of the high fibrous contents found in the reproductive stage; Paiva and Oliveira (2006) reported that the high leaf-to-stem ratio and high composition of soluble carbohydrates, which act as substrates for fermentation and consequent $\mathrm{pH}$ reduction, favor more efficient degradation of the fiber, providing a high-quality silage for animals, in relation to the widely used fodder materials.

No significant difference in $\mathrm{pH}$ was observed between grasses $(\mathrm{P}>0.05)$, only between stages, being higher in the vegetative than in the reproductive stage (Table 3 ). The $\mathrm{pH}$ values were higher than those found by Meinerz et al. (2011), who evaluated the silage of different dual-purpose temperate grasses and found the $\mathrm{pH}$ values ranging between 3.73 and 4.39 .

The $\mathrm{pH}$ of the silage is directly related to the DM content of the plant at the moment it is ensiled. Owing to the high moisture content in the vegetative stage, temperate grasses must undergo a prior dehydration process to ensure adequate DM contents for proper fermentation of the material, making it difficult to develop aerobic microorganisms, such as Clostridium ssp., that can deteriorate silage (SIQUEIRA et al., 2007; SANTOS et al., 2010; COBLENTZ et al., 2014). Although the $\mathrm{pH}$ values recorded in this study were higher than those indicated by some authors (PEREIRA et al., 2007; LIU et al., 2016; RAZMKHAH et al., 2017), who recommended $\mathrm{pH}$ variations between 3.5 and 4.5 , the DM content of the ensiled material in this study was considered adequate (McDONALD et al., 1991), compensating any problem related to inadequate fermentation, which, in turn, is related to this parameter $(\mathrm{pH})$ that can be considered of little relevance when the contents of pre-ensiled DM are above 35\% (FRANÇA et al., 2007).

In general, the critical $\mathrm{pH}$ value of silage varies directly with the dry matter content of the ensiled plant; the higher the dry matter content, the higher is the $\mathrm{pH}$ value, unless the soluble carbohydrate levels are exceptionally high. Furthermore, as mentioned above, the $\mathrm{pH}$ value has a close relationship with the mineral content of the plant, with high contents of mineral matter increasing the resistance of the material to $\mathrm{pH}$ oscillation. However, this does not have a great influence on the final quality of the silage, if factors, such as compaction and anaerobiosis, are considered.

The highest losses due to effluents were verified at the vegetative stage, being the observed effects of the stages and grass species evaluated. Rye presented the least amount of effluent loss. Zamarchi et al. (2014) reported that losses might occur during 
the conservation process because of the intrinsic characteristics of the forage silage, as well as the stage of maturation and chemical composition of the forage species. Corroborating these findings, Santos et al. (2010) showed that these factors can act alone or jointly, reflecting on the fermentative process according to each cultivar. The production of metabolic water in the fermentation process can also occur, especially in the presence of $\mathrm{O}_{2}$. Thus, even with adequate moisture content, if there is adequate compaction, there might be a loss of nutrients by aerobiosis and leaching with the water synthesized as long as there is $\mathrm{O}_{2}$ in the medium. However, the losses presented a positive correlation with the protein content $(0.67, \mathrm{P}=0.0001)$ and a negative correlation with the NDF contents $(-0.41$, $\mathrm{P}=0.0009)$, affirming that higher NDF levels help reduce leaching losses.

\section{Conclusion}

The rye presents relatively less variation of the nutritional composition between the studied phenological stages.

The mineral content of the forage influences the $\mathrm{pH}$ of the silage, with the highest $\mathrm{pH}$ recorded in the vegetative stage.

Even with wilting, the vegetative stage presents greater losses by effluents when compared to the reproductive stage.

\section{Acknowledgements}

We thank the Coordination of Superior Level Staff Improvement (Coordenação de Aperfeiçoamento de Pessoal de Nível Superior-CAPES) for financial support of this study (finance code 001).

\section{References}

AGUINAGA, A. A. Q.; CARVALHO, P. C. F.; ANGHINONI, I.; PILAU, A.; AGUINAGA, A. J. Q.; GIANLUPPI, G. D. F. Componentes morfológicos e produção de forragem de pastagem de aveia e azevém manejada em diferentes alturas. Revista Brasileira de Zootecnia, Viçosa, MG, v. 37, n. 9, p. 1523-1530, 2008. DOI: $10.1590 / \mathrm{S} 1516-35982008000900002$.

ANDRIGUETTO, J. M.; PERLY, L.; MINARDI, I.; GEMAEL, A.; FLEMMING, J. S.; SOUZA, G. A.; BONA FILHO, A. Nutrição animal: bases e os fundamentos da nutrição animal e os alimentos: São Paulo, SP: Editora Nobel, 2002. v. 1, 395 p.

ASSOCIATION OF OFFICIAL ANALYTICAL CHEMISTS - AOAC. Official methods of analysis of the Association of Official Analytical Chemistry. $16^{\text {th }}$ ed. Maryland: AOAC International,, 1998.

ASSOCIATION OF OFFICIAL ANALYTICAL CHEMISTS - AOAC. Official methods of analysis of the Association of Official Analytical Chemistry. $16^{\text {th }}, 3^{\text {th }}$ ed. Gaithersburg: AOAC International, 1997.

BHERING, S. B.; SANTOS, H. G. dos; BOGNOLA, I. A.; CÚRCIO, G. R.; MANZATTO, C. V.; CARVALHO JUNIOR, W. de; CHAGAS, C. da S.; ÁGLIO, M. L. D.; SOUZA, J. S. de. Mapa de solos do Estado do Paraná: legenda atualizada. Rio de Janeiro: EMBRAPA/IAPAR, 2008. $74 \mathrm{p}$.

BOIN, C.; FLOSS, E. L.; CARVALHO, M. P.; PALHANO, A. L.; SOARES FILHO, C. V.; PREMAZZI, L. M. Composição e digestibilidade de silagens de aveia branca produzidas em quatro estádios de maturação. Boletim de Indústria Animal, Nova Odessa, v. 62, n. 1, p. 35-43, 2005.

BROUGHAM, R. M. Effects of intensity of defoliation on regrowth of pastures. Australian Journal of Agricultural Research, Melbourne, v. 7, n. 5, p. 377-387, 1956. DOI: 10.1071/AR9560377.

COBLENTZ, W. K.; MUCK, R. E.; BORCHARDT, M. A.; SPENCER, S. K.; JOKELA, W. E.; BERTRAM, M. G.; COFFEY, K. P. Effects of dairy slurry on silage fermentation characteristics and nutritive value of alfalfa. Journal of Dairy Science, Champaign, v. 97, n. 11, p. 7197-7211, 2014. DOI: 10.3168/jds.2014-8582.

COMISSÃO DE QUÍMICA E FERTILIDADE DO SOLO - CQFS RS/SC. Manual de adubação e de calagem para os Estados do Rio Grande do Sul e de Santa Catarina. Porto Alegre: Sociedade Brasileira de Ciência do Solo. Comissão de Química e Fertilidade do Solo, 2004. 400 p.

COSTA, O. A. D.; FERREIRA, O. G. L.; SILVA, J. L. S.; FLUCK, A. C.; KRÖNING, A. B.; OLIVEIRA, L. V.; COELHO, R. A. T.; BRONDANI, W. C. Yield, structural composition and nutritive characteristics of ryegrass cultivars used to haymaking in lowland soils. Bioscience Journal, Uberlândia, v. 34, n. 5, p. 1232-1238, sept. /oct. 
2018. DOI: 10.14393/BJ-v34n5a2018-39405.

DETMANN, E.; SOUZA, M. A.; VALADARES FILHO, S. C.; QUEIROZ, A. C.; BERCHIELLI, T. T.; SALIBA, E. O. S.; CABRAL, L. S.; PINA, D. S.; LADEIRA, M. M.; AZEVEDO, J. A. G. (Ed.). Métodos para análise de alimentos. Visconde do Rio Branco: Suprema, 2012. 214 p.

FEROLLA, F. S.; VASQUEZ, H. M.; SILVA, J. F. C.; VIANA, A. D.; DOMINGUES, F. N.; AGUIAR, R. S. Produção de matéria seca, composição da massa de forragem e relação lâmina foliar/caule + bainha de aveiapreta e triticale nos sistemas de corte e pastejo. Revista Brasileira de Zootecnia, Viçosa, MG, v. 36, n. 5, p. 15121517, 2007. DOI: 10.1590/S1516-35982007000700008.

FLUCK, A. C.; COSTA, O. A.; SCHAFHÄUSER JÚNIOR, J.; ROSA, P. P.; CARDOZO, L.; SCHEIBLER, R. B.; RIZZO, F. A.; ALFAYA JÚNIOR, H. In vitro and in situ digestibility of annual ryegrass silage from distinct phenological growth stages and pre-dehydration times. Bioscience Journal, Uberlândia, v. 34, n. 5, p. 12391247, 2018a. DOI: 10.14393/BJ-v34n5a2018-39421.

FLUCK, A. C.; SCHAFHÄUSER JÚNIOR, J.; ALFAYA JÚNIOR, H.; COSTA, O. A. D.; FARIAS, G. D.; SCHEIBLER, R. B.; RIZZO, F. A.; MANFRON, J. A. S.; FIOREZE, V. I.; RÖSLER, D. C. Chemical composition of annual ryegrass forage and silage for different drying times and phenological phases. Arquivo Brasileiro de Medicina Veterinária e Zootecnia, Belo Horizonte, v. 70, n. 6, p. 1979-1987, 2018b. DOI: 10.1590/1678-41629981.

FONTANELI, R. S.; FONTANELI, R. S. Ensilagem. In: FONTANELI, R. S.; SANTOS, H. P. dos; FONTANELI, R. S. (Ed.). Forrageiras para integração lavourapecuária-floresta na região sul-brasileira. 2. ed. Brasília: EMBRAPA, 2012. 274 p.

FONTANELI, R. S.; FONTANELI, R. S.; SANTOS, H. P. dos; NASCIMENTO JUNIOR, A. do; MINELLA, E.; CAIERÃO, E. Rendimento e valor nutritivo de cereais de inverno de duplo propósito: forragem verde e silagem ou grãos. Revista Brasileira de Zootecnia, Viçosa, MG, v. 38 , n. 111 , p. $2116-2120$, 2009. DOI: 10.1590/S151635982009001100007.

FRANÇA, A. F. S.; OLIVEIRA, R. P.; RODRIGUES, J. A. S.; MIYAGI, E. S.; SILVA, A. G.; PERON, H. J. M. C.; ABREU, J. B. R.; BASTOS, D. C. Características fermentativas da silagem de híbridos de sorgo sob doses de nitrogênio. Ciência Animal Brasileira, Goiânia, v. 12, n. 3, p. 383-391, 2011.

GRUPO DE ESTUDOS EM BIOMETEOROLOGIA GEBIOMET. Dados clima 2012 e 2013. Dois Vizinho:
Universidade Tecnológica Federal do Paraná - UTFPR, 2016. Disponível em: http://www.gebiomet.com.br/. Acesso em: 23/05/2016.

JOBIM, C. C.; NUSSIO, L. G.; REIS, R. A.; SCHMIDT, P. Avanços metodológicos na avaliação da qualidade da forragem conservada. Revista Brasileira de Zootecnia, Viçosa, MG, v. 36, 2007. Suplemento Especial. DOI: 10.1590/S1516-35982007001000013.

KOZLOSKI, G. V.; PEROTTONI, J.; SANCHEZ, L. M. B. Influence of regrowth age on the nutritive value of dwarf elephant grass hay (Pennisetum purpureum Schum. cv. Mott) consumed by lambs. Animal Feed Science and Technology, Amsterdam, v. 119, n. 1-2, p. 1-11, 2005. DOI: 10.1016/j.anifeedsci.2004.12.012.

LIU, Q. H.; SHAO, T.; BAI, Y. F. The effect of fibrolytic enzyme, Lactobacillus plantarum and two food antioxidants on the fermentation quality, alphatocopherol and beta-carotene of high moisture napier grass silage ensiled at different temperatures. Animal Feed Science and Technology, Amsterdam, v. 221, Part A, p. 1-11, 2016. DOI: 10.1016/j.anifeedsci.2016.08.020.

LOPES, F. C. F.; SILVA E OLIVEIRA, J.; LANES, E. C. M.; DUQUE, A. C. A.; RAMOS, C. R. Valor nutricional do triticale (Tritico secale Wittmack) para uso como silagem na Zona da Mata de Minas Gerais. Arquivo Brasileiro de Medicina Veterinária e Zootecnia, Belo Horizonte, v. 60, n. 6, p. 1484-1492, 2008. DOI: 10.1590/ S0102-09352008000600027.

McDONALD, P. The biochemistry of silage. New York: John Wiley, 1981. 207 p.

McDONALD, P.; HENDERSON, A. R.; HERON, S. J. E. The biochemistry of silage. $2^{\text {th }}$ ed. Marlow: Chalcombe Publications, 1991. $226 \mathrm{p}$.

MEINERZ, G. R.; OLIVO, C. J.; VIÉGAS, J.; NÖRNBERG, J. L.; AGNOLIN, C. A.; SCHEIBLER, R. B.; HORST, T.; FONTANELLI, R. S. Silagem de cereais de inverno submetidos ao manejo de duplo propósito. Revista Brasileira de Zootecnia, Viçosa, MG, v. 40, n. 10 , p. $2097-2104$, 2011. DOI: $10.1590 / \mathrm{S} 1516-$ 35982011001000005 .

MERTENS, D. R. Gravimetric determination of amylasetreated neutral detergent fiber in feeds with refluxing in beaker or crucibles: collaborative study. Journal of AOAC International, Rockville, MD, v. 85, n. 6, p. $1217-$ 1240, 2002.

MESQUITA, E. E.; NERES, M. A. Morfogênese e composição bromatológica de cultivares de Panicum maximum em função da adubação nitrogenada. Revista Brasileira de Saúde e Produção Animal, Salvador, v. 9, n. 2, p. 201-209, 2008. 
PAIVA, R.; OLIVEIRA, L. M. Fisiologia e produção vegetal. Lavras: UFLA, 2006. 104 p.

PARIS, W.; ZAMARCHI, G.; PAVINATO, P. S.; MARTIN, T. N. Qualidade da silagem de aveia preta sob efeito de estádios fenológicos, tamanhos de partícula e pré-murchamento. Revista Brasileira de Saúde e Produção Animal, Salvador, v. 16, n. 3, p. 486-498, 2015. DOI: $10.1590 / \mathrm{S} 1519-99402015000300002$.

PEREIRA, E. S.; MIZUBUTI, I. Y.; PINHEIRO, S. M.; VILARROEL, A. B. S.; CLEMENTINO, R. H. Avaliação da qualidade nutricional de silagens de milho (Zea mays, L). Revista Caatinga, Mossoró, v. 20, n. 3, p. 8-12, 2007.

PEREIRA, J. R. A.; REIS, R. A. Produção de silagem présecada com forrageiras de clima temperadas e tropicais. In: SIMPÓSIO SOBRE PRODUÇÃO E UTILIZAÇÃO DE FORRAGENS CONSERVADAS, 2001, Maringá. Anais... Maringá: Universidade Estadual de Maringá, 2001. p. 64-86.

PLAYNE, M. J.; McDONALD, P. The buffering constituents of herbage and of silage. Journal of the Science of Food and Agriculture, v. 17, n. 6, p. 264-268, 1966. DOI: $10.1002 /$ jsfa.2740170609.

RAZMKHAH, M.; RAZAEI, J.; FAZAELI, H. Use of Jerusalem artichoke tops silage to replace corn silage in sheep diet. Animal Feed Science and Technology, Amsterdam, v. 228, p. 168-177, 2017. DOI: 10.1016/j. anifeedsci.2017.04.019.

RODRIGUES, R. C.; COELHO, R. W.; REIS, J. C. Rendimento de forragem e composição química de cinco gramíneas de estação fria. Pelotas: EMBRAPA, 2002. 3 p. (Comunicado técnico, 77).

SANTOS, M. V. F.; CASTRO, A. G.; PEREA, J. M.; GARCIA, A.; GUIM, A. Fatores que afetam o valor nutritivo das silagens de forrageiras tropicais. Archivos de Zootecnia, Córdoba, v. 59, Revisiones, p. 25-43, 2010.
SIQUEIRA, G. R.; REIS, R. A.; SCHOCKENITURRINO, P.; BERNARDES, T. F.; PIRES, A. J. V.; ROTH, M. T. P.; ROTH, A. P. T. P. Associação entre aditivos químicos e bacterianos na ensilagem de canade-açúcar. Revista Brasileira de Zootecnia, Viçosa, MG, v. 36, n. 4, p. 789-798, 2007. DOI: 10.1590/S151635982007000400006 .

SKONIESKI, F. R.; VIÉGAS, J.; BERMUDES, R. F.; NÖRNBERG, J. L; ZIECH, M. F.; COSTA, O. A. D.; MEINERZ, G. R. Composição botânica e estrutural e valor nutricional de pastagens de azevém consorciadas. Revista Brasileira de Zootecnia, Viçosa, MG, v. 40, n. 3, p. 550-556, 2011. DOI: 10.1590/S151635982011000300012 .

SOUZA, G. B. de.; NOGUEIRA, A. R. A.; RASSINI, J. B. Determinação de matéria seca e umidade em solos e plantas com forno de microondas doméstico. São Carlos: EMBRAPA Pecuária Sudeste, 2002. 9 p. (Circular Técnica, 33).

SAS/STAT ${ }^{\circledR}$ 13. 1 User's Guide. Cary: SAS Institute Inc., 2013. 9496 p.

VAN SOEST, P. J. Nutritional ecology of the ruminant. $2^{\text {th }}$ ed. Ithaca: Cornell University, 1994. $476 \mathrm{p}$.

VANBELLE, M; ARNOULD, R.; DEWYSEN, A.; MOREAU, I. Inkuilen een actueel probleem. Leuven: Iwonl, 1983. $81 \mathrm{p}$.

ZAMARCHI, G.; PAVINATO, P. S.; MENEZES, L. F. G.; MARTIN, T. N. Silagem de aveia branca em função da adubação nitrogenada e pré- murchamento. Semina: Ciências Agrárias, Londrina, v. 35, n. 4, p. 2185-2196, 2014. DOI: 10.5433/1679-0359.2014v35n4p2185.

ZANINE, A. M.; MACEDO JUNIOR, G. L. Importância do consumo da fibra para nutrição de ruminantes. Revista Eletrónica de Veterinária, Málaga, n. 7, v. 4, p. 1-12, 2006. 
